CHAPTER 8

\title{
Institutions of Collective Action and Smallholder Performance: Evidence from Senegal
}

Fleur Wouterse and Amy Faye ${ }^{1}$

1 The authors would like to thank Khadim Dia for help with the data, Gian Nicola Francesconi for reading through and commenting on a previous version of this manuscript, and Mohamadou Dieye who provided some of the figures. 
S enegal is a country where farming has remained largely smallholder based. Although the country's economy has grown by at least 6 percent annually since 2014 and poverty rates have declined from 45.8 percent in 2003 to 23.0 percent in 2018, the agricultural growth rate has remained well below the 6.0 percent target of the Comprehensive Africa Agriculture Development Programme, and rural poverty rates have remained high (ReSAKSS 2020). Due to high population growth, increased pressure on land, and precarious climate conditions, rural-urban migration is high and 296,000 young people are said to arrive each year on the labor market, with formal job offers estimated at only 30,000 (Ba et al. 2017. Since 2012, Senegal has reprioritized its investments to catalyze an agriculturally led structural transformation. The Plan Senegal Emergent (PSE) envisages agriculture as an engine of growth that will spur balanced economic and social development across multiple sectors. The Programme d'Accélération de la Cadence de l'Agriculture Sénégalaise (PRACAS) — the agricultural component of PSEemphasizes the promotion of family farming through intensification, more and better market participation, and quality management.

Arguably Africa's rural transformation is hampered by the fact that smallholder agriculture is exposed to persistent market failures, culminating in missed opportunities and suboptimal economic behavior. These failures are often rooted in the importance of economies of scale in procuring inputs and marketing produce. Over the past few years, stakeholders throughout Africa south of the Sahara have expressed a renewed interest in collective action mechanisms such as producer organizations as a means to help smallholders address market failures. In theory, by engaging in collective action, smallholders could have better access to and derive more benefits from market participation. Studies have shown that smallholders derive benefits from membership in a producer organization mainly through access to improved inputs and extension (Ma, Abdulai, and Goetz 2018; Abdul-Rahman and Abdulai 2018) but to a lesser extent through more favorable terms for sales of their output (Bernard, Taffesse, and Gabre-Mahdin. 2008; Francesconi and Wouterse 2015a). This poor performance in terms of collective commercialization has been attributed, in part, to weak managerial capacity.

Senegal has a wealth of rural institutions as well as strong national-level organizations representing producer interests. Because objectives of PRACAS such as intensification of family farming and more and better participation in markets require scale, capitalizing on this institutional infrastructure could contribute to their attainment. However, to be able to advocate for the consideration of producer organizations as going beyond mere channels for subsidized inputs, we need to assess whether membership in an organization is associated with intensification of smallholder agriculture and whether these organizations generate economies of scale through collective commercialization.

In this chapter, we use recent data on almost 7,000 smallholders and 395 water user associations (WUAs), along with propensity score matching (PSM) and regression analysis, to quantitatively assess whether membership in producer organizations affects technical efficiency of smallholders and whether the design and governance of such organizations affects the organizations' performance. Our results reveal that membership is associated with greater efficiency and that the design of organizations and their governance can enhance their commercial performance. Policymakers would thus do well to work with producer organizations and further build their governance capacity and membership base for successful implementation of the country's agricultural development strategy.

\section{Evolution and Drivers of Collective Action in Agriculture in Africa}

As pointed out earlier, smallholder agriculture in Africa south of the Sahara is largely exposed to pervasive market failures that are often rooted in a lack of economies of scale in both procuring inputs and marketing outputs. In such a context, developing or capitalizing on an institutional infrastructure that facilitates market exchange for smallholders is critically important. By engaging in collective action, smallholders are likely to have better access to markets and derive more benefits from market participation. Over the past few years, stakeholders throughout Africa south of the Sahara have expressed a renewed interest in collective action mechanisms such as producer organizations as a means to help smallholders address market failures.

Producer organizations are membership-based organizations or federations of organizations with elected leaders accountable to their constituents. They take on various legal forms - such as cooperatives, associations, and groups. They can be grouped into four categories, according to their respective functions: (1) commodity-specific organizations focusing on economic services and defending their members' interests in a particular commodity; (2) advocacy organizations to represent producers' interests, such as national producers' unions; (3) associations of users of a natural resource, such as WUAs; and (4) multipurpose organizations 
that respond to the diverse economic and social needs of their members, often in the absence of local governments or effective public services (World Bank 2007).

In precolonial Africa, agricultural production was organized into communities of subsistence smallholders, with governance based on kinship and hierarchical principles (Buell 1928). The risk associated with subsistence farming was commonly shared within a community through various revolving or rotating schemes (Strickland 1933). These mechanisms were intended to facilitate the exchange of labor, food, and other resources among community members in times of need and continue to exist in many countries, for example, the tontine (rotating savings and credit associations) in Senegal, grenier villageoise (community granary) in Burkina Faso and Niger, the idir (funeral society) and iqub (savings club) in Ethiopia, and the nnoboa (mutual help group) and susu (rotating savings and credit association) in Ghana. Although such structures continue to serve important social protection functions, arguably their contribution to agricultural development has been negligible (Francesconi and Ayerakwa 2011; Salifu, Francesconi, and Kolavalli 2010).

Colonial authorities, recognizing the social importance of community-based arrangements for risk-sharing purposes, leveraged them to establish cooperatives that could facilitate the bulking and commercialization of agricultural products (Francesconi and Wouterse 2015b). During that time, cooperatives in Africa were used by the colonial powers as a strategic tool to group rural producers into clusters, so that essential export commodities such as coffee, cocoa, and cotton could be collected more cost-effectively. After independence, the governments of the now sovereign states accorded an essential role to cooperatives, in particular for the development of rural areas. Cooperatives enjoyed preferential treatment and were granted supply and marketing monopolies that protected them from competition. They paid for these privileges, however, with the loss of autonomy, democratic control, and economic efficiency. Cooperatives essentially became tools of government. This was the situation in many African countries at the onset of the era of structural adjustment in the late 1980s. Structural adjustment resulted in the withdrawal of the state from economic and development functions, and the sudden liberalization of state-controlled cooperatives. Most development partners promoted the concepts of liberalization, deregulation, and privatization-in this context, cooperatives were considered an obsolete model. The disintegration of many state-controlled cooperative movements in the 1990s seemed to confirm this observation. Yet the more recent liberalization of the economy does appear to steadily offer many cooperatives the opportunity to reinvent their solidarity and generate collective action among their members to tap into economies of scale and improve the productivity of their members.

\section{Historical Context of Smallholder Cooperation in Senegal}

In Senegal, agriculture is largely smallholder based. A peasant movement exists with a vast number of rural institutions in thousands of villages as well as strong national-level farmer organizations. The history of agricultural and development policy in Senegal since its 1959 independence can be divided into two main periods: two decades of state intervention (from independence to the late 1970s) followed by two decades of liberalization (from the late 1970ss to 2000) that has become more and more complete. One of the first issues that preoccupied the newly independent country was the organization of rural producers. The decree of 1959 that proposed the creation of agricultural cooperatives expressed the government's vision of a mechanized, prosperous agricultural sector. The 800 cooperatives that were formed by the promulgation of the law primarily occupied themselves with the commercialization of groundnuts, Senegal's most important export crop at the time. These cooperatives were supposed to replace one of the most visible signs of the colonial structure: foreign merchants who bought groundnuts and sold their goods to villagers in exchange. However, rural expansion slowed in the early 1960s with the ousting of Prime Minister Mamadou Dia, and without support, the cooperatives ended up as an instrument of imposition for rural producers rather than one of expression. During this time, support from the international community paved the way for the creation and development of regional organizations for rural development with a mission to specialize and transform agricultural systems in the different agroecological zones. These organizations were focused on a particular crop and therefore could not grapple with the reality of rural smallholders, who usually cultivated multiple crops, nor with the socioeconomic logic of the household as production unit. These regional organizations mainly engaged in extension to convince farmers to adopt the technological packages that they were recommending.

At the beginning of the 1970s, this system of rural development came into crisis due to a fall in export prices on the world market-for groundnuts in particular-a heavy bureaucracy, the progressive and serious indebtedness of farmers, and severe droughts that affected the Sahel in 1973/1974. During 
this period, the first independent farmers' organizations appeared throughout the country, with farmers deciding to take their fate into their own hands and seeking to solve the problems that the state had apparently been unable to address. In some cases, the initiative was taken by young adults who had traveled and returned to their village of origin with plenty of ideas. Members tended to be women and young people, who were not well represented in traditional structures. Through negotiations for space with village elders and by establishing hard-fought peace with local administrators, these associations became more and more widespread throughout the country.

In 1978 the Federation of Non-governmental Organizations of Senegal (FONGS) was established, with the overall objectives of reinforcing solidarity among farmer groups, communicating with member organizations and foreseeing their training needs, supporting the development initiatives of village-level organizations, and serving as an interface between its members and the external world. For the first 10 years or so, FONGS limited itself to serving as a framework and managing training and exchange programs for new members, with support from a wide range of donors. The start of the period of structural adjustment and the withdrawal of the state, as well as the drought of 1984/1985, marked the start of a new phase in its history. The new agricultural policy, which followed the near bankruptcy of the country and a bailout by the International Monetary Fund, advocated the complete withdrawal of the state from agriculture and rejected the interventionist policy, which the government had adopted up until then. Regional parastatal development organizations were to be dismantled, extension and other services were to be reduced, prices were to be liberalized and input subsidies reduced or eliminated, credit was to be restricted and reorganized, and farmers were encouraged to take over, together with the private sector, the functions and services previously fulfilled by the state. To do so, the government facilitated the emergence of a new category of organizations, with a more flexible legal status: economic interest groups (EIGs), which could be created by at least two people who wanted to undertake a business activity, obtain credit, and so on. These groups rapidly developed due to the support for their creation and the special treatment they received for obtaining credit from the national agricultural credit fund, or Caisse Nationale de Credit Agricole (CNCA), and started to organize themselves at the national level at the end of the 1980s according to different chains (fish, horticulture, livestock, and so on). FONGS, feeling threatened by the powers of this new umbrella and wanting to defend its own interests, undertook more ambitious initiatives at the national level—such as cereal banks and "triangular" exchanges between village-level organizations in surplus and deficit zones. Confronted with suspension of rural credit subsidized by the government, FONGS also provided inputs and agricultural equipment through a savings and credit arrangement. By the same token, FONGS bought shares and became part of the board of directors of the CNCA.

In 1993, FONGS was instrumental in creating the platform of a national rural consultative committee called Le Comité National de Concertation des Ruraux (CNCR), consisting of seven national federations of farmers, livestock producers, fishers and horticultural producers, and rural women. Two years later, two other federations, of forest exploiters, joined the CNCR, bringing its total number of members up to about 3 million. The objective of the CNCR at the outset was to promote dialogue and the exchange of experience between its members, to encourage the pooling of resources and competencies, and to serve as a voice for the farmer movement, versus the state and donors, regarding questions related to national development. A couple of years later, the CNCR needed to develop a mechanism that could disburse funds from the World Bank, the International Fund for Agricultural Development, and a government-managed program of almost US $\$ 30$ million, to be used for "small rural projects" and to offer services to rural producers. Negotiations with the government and the World Bank led to the creation, in 1996, of a grassroots development organization called Association Sénégalaise pour la Promotion du Développement à la Base (ASPRODEB), which aimed to augment the economic resources of rural producers, family enterprises, and their organizations by reinforcing access to finance and markets, and by reinforcing their professional capacities. The association, which has the status of nongovernmental organization, implements its activities through a technical arm (McKeon 2002). ASPRODEB manages the Agricultural Services and Producer Organizations Program, which is essentially a partnership between producer organizations and agricultural services, intended to reduce rural poverty, and was initiated by the CNCR (De Janvry and Sadoulet 2004). Beginning in 2000, CNCR became involved in the creation of a peasant movement for West Africa to provide a platform for representation of producers in the subregion at the regional and international levels. It thus prompted the creation of a West African regional umbrella organization, Réseau des Organisations Paysannes et des Producteurs de l'Afrique de l'Ouest. 
In Senegal, as in other countries, management of irrigation perimeters is done at the community level. Decentralization to local institutions is expected to generate benefits for the community, contributing to a more sustainable use of resources over time. WUAs were formed as intermediate organizations for common property management. These associations are present throughout Senegal in areas where horticulture is prominent.

\section{Producer Organizations and Smallholder Agriculture}

In a context like that of Senegal, and indeed much of Africa south of the Sahara, engagement in collective action through membership in a producer organization is likely to lead to increased market access for smallholder farmers. Services provided by producer organizations, such as those related to supply, marketing, and bargaining provision, are formally akin to club goods (Deininger 1995). By opening access to economies of scale for both inputs and outputs, these services can help mitigate the market failures that have plagued smallholders.

\section{Supply, Marketing, and Bargaining Services}

Better access to input markets could lead to adoption of yield-enhancing technologies such as fertilizers and pesticides, which are expected to positively affect yields and farm revenue (Abebaw and Haile 2013; Verhofstadt and Maertens 2014). Larger yields can be achieved not just by increasing the levels of input use but also by changing how different inputs are combined and the efficiency of their use. Abate, Francesconi, and Getnet (2014) found that agricultural cooperatives in Ethiopia provided services that significantly contributed to members' technical efficiency. Ma, Abdulai, and Goetz (2018) concluded that technical efficiency among Chinese apple farmers was consistently higher for cooperative members, relative to their counterparts. Abdul-Rahaman and Abdulai (2018) showed that for rice farmers in Ghana, participation in farmer groups was associated with increased yield and technical efficiency, relative to farmers who produced and marketed rice individually.

Producer organizations often provide farmers with information, such as marketing channels and market prices, which enables them to sell their produce at higher prices. For example, Wollni and Zeller (2007) showed that participation in cooperatives enhanced access to specialty coffee markets and increased prices for coffee farmers in Costa Rica. In their analysis on China, Hoken and Su (2018) revealed that a higher price margin obtained by cooperative members was a major factor that increased their net rice income.

Arguably, the best way to capture economies of scale would be for producer organizations to centralize production and engage in commercialization.

However, evidence of the ability of producer organizations to engage in remunerative collective commercialization has remained somewhat elusive. Bernard and colleagues (2008) found for Ethiopia that although cooperatives did obtain higher prices for their members, they were not associated with a significant increase in the overall share of cereal production sold commercially by their members (see also Francesconi and Heerink 2011). The limited extent to which producer organizations in Africa have been able to generate economic benefits for their members has been attributed to their inability to resolve some of the inherent tensions that characterize collective action and that tend to become manifest in time (Francesconi and Wouterse 2015a).

\section{Sustainability of Collective Action Arrangements}

Producer organizations are member-driven-as opposed to investor-drivenassociations of smallholders, that is, organizations in which the right to make decisions resides with the members. Many of the potential benefits that these groups offer to their members stem from the fixity of assets-both physical and human-in farming and other types of agribusiness. Asset fixity means that when assets are specialized, as is agricultural machinery, which has limited use outside of agriculture, autonomous market contracting is a less efficient means of allocating them (Williamson 1981). As an asset becomes more specific, its resale value diverges from its acquisition value. The divergence between the acquisition and resale value of an asset gives rise to rents that are potentially appropriable through market transactions if insufficient competition in the market permits one of the parties to the transaction to act opportunistically (Staatz 1987). Hence, the combination of small numbers in the product market and asset fixity, itself often a function of poorly functioning factor markets, can lead to situations in which individual farmers are at considerable risk in their dealings with their trading partners. Collective action by these individual farmers through forming or joining a producer organization can help minimize transaction costs and reduce risks. However, benefits derived from membership are likely to vary over time. In fact, analysis of agricultural cooperatives in the United States led to the development of a cooperative life-cycle framework, which emphasizes that 
increasing heterogeneity in member preferences may threaten the sustainability of the cooperative organization because competing member-patron interests have the potential to increase collective decision-making costs (Cook and Chambers 2007).

During the process of creating a new cooperative, members tend to be infused with enthusiasm for their new enterprise, with solidarity bred of their common experience, and cohesion shaped by a common background and the sense of successfully overcoming a big challenge. The dedication of these members to their new enterprise and to each other motivates them to act in ways that defy individual rationality based on self-interest. They do not require complicated incentive and monitoring schemes to exercise desirable effort and to refrain from shirking. Such members exert social pressure on each other to ensure that free riders raise their effort levels or leave the cooperative (Ben-Ner and Ellman 2013). However, solidarity may wane over time as the initial conditions are replaced by normality and as membership turnover introduces new members, who seldom replicate the energy and values of the original members; new members tend to join the organization one at a time, without the same sense of ownership and togetherness. When financial motivation, centered on individual self-interest, becomes dominant, the organizational design, based on collective decision making and sharing of profits, becomes a source of weakness rather than strength. The design is vulnerable to exploitation by selfish and relatively unprincipled members. Over time, shirking in various forms, such as free riding on team contributions, is likely to become increasingly prevalent. When member commitment is affected by heterogeneous preferences, selfish actions may prevail and members may decide not to invest in the organization, that is, to free ride on investments made by others (Staatz 1987). Members can also behave opportunistically by not providing patronage, for example, by side-selling their output to competing traders or processors, to whom they have no repayment obligation (Wouterse and Francesconi 2016).

In her work on common-pool resources, Ostrom (1990) identified some factors that are crucial to the longevity of organizations of collective action. The first is clearly defined boundaries, meaning that those who have the right to withdraw resource units from the common pool must be clearly defined, as must be the boundaries of the common pool itself. Defining the boundaries of the association and specifying those authorized to use it can be thought of as a first step in organizing collective action (Tadesse, Abate, and Ergano 2019).
In general, as a firm or an organization expands its service range, the unit cost of providing those services might fall initially, as expertise, information, and indivisible physical assets are utilized more efficiently. For instance, in the case of agricultural marketing cooperatives, Bernard and Taffesse (2012) showed that expanding the range of activities may not necessarily impair commercial performance if the newly added activities are closely related to the commercialization purpose. Thus, a variety of complementary services may increase members' patronage and, hence, the cooperative's competitiveness. However, scope economies are obtained by enlarging the number of activities that are ultimately bounded. Because each service carries certain (fixed) costs, overdiversification can increase unit costs. For agricultural cooperatives, three main sources of diseconomies of scope arise: increased cooperative coordination costs (Bernard and Taffesse 2012), increased member transaction costs, and reduced membership commitment. Tadesse, Abate, and Ergano (2019) demonstrated that, for cooperatives in Ethiopia, a clearly defined boundary - that is, provision of a limited range of appropriate services-was crucial for improving the competitiveness of these organizations.

Ostrom (1990) also emphasized that usage and provision rules need to reflect local conditions. Rules of use, restricting time, place, technology, and/or quantity of resource units, are related to local conditions and to provision rules requiring contributions of labor, materials, money, or some combination of these. The durability of the organization is also influenced by the fact that rules can be modified by those affected. Most production technologies entail some degree of joint production: individual contributions cannot be identified separately from each other. In principle, a monitoring system can resolve the joint production problem (Ben-Ner and Ellman 2013). Ostrom (1990) pointed out that monitors need to be accountable to users of the resource, or even be the users of the resource.

Ostrom (1990) also mentioned that graduated sanctions need to be applied to users who violate operational rules, to avoid shirking or free riding. Member obligations mean that free riding can be avoided and economies of scale can be exploited. Also, by enforcing these obligations, the organization signals to members that excluding noncontributors from services is possible and that members can expect to reap the full returns on their commitments. It should be noted that even if an organization of collective action offers excludable services, it still generates communitywide externalities (Tadesse, Abate, and Ergano 2019). 
Ostrom (1990) also emphasized the importance of conflict resolution mechanisms: appropriators and their officials should have rapid access to low-cost local arenas to resolve conflicts among appropriators or between users and officials. Profit sharing has been identified as a relatively stable and conflictreducing distributive rule (Ben-Ner and Ellman 2013). Profit sharing is also valuable for informal agreements. Equal sharing is a particularly clear rule that can be applied quite generally, reducing the scope for self-serving interpretation and misunderstandings; in addition, its attractive fairness properties make it a salient option for mutual agreement.

A key point that arises from work of Ostrom (1990) and was further emphasized by Francesconi and Wouterse (2015a) is that in "robust" institutions, monitoring and sanctioning are undertaken by the participants themselves. This means that the rights of users to devise their own institutions or rules are not challenged by external governmental authorities.

\section{Data}

According to recent data from a project in Senegal called the Projet d'Appui aux Politiques Agricoles (PAPA), at the national level, 17 percent of smallholders are members of an organization. ${ }^{2}$ The membership rate is lower-at around 9 percent-for producers of dry cereals. Producers of horticultural crops, mainly located in the coastal north, and irrigated rice farms in the Senegal River Valley and the Anambe Basin in the south, have higher rates of membership in producer organizations (about 38 percent and 33 percent, respectively). These are slightly higher than the rates found in the literature in earlier years. The country's national statistics agency, ANSD (2014), reported for the 2013 national census that 11.4 percent of farm households were members of a farmer organization. ${ }^{3}$ Figure 8.1 displays the density of membership, defined as the number of smallholders who are members of an organization,
FIGURE 8.1-DENSITY OF MEMBERSHIP IN FARM ORGANIZATIONS IN SENEGAL

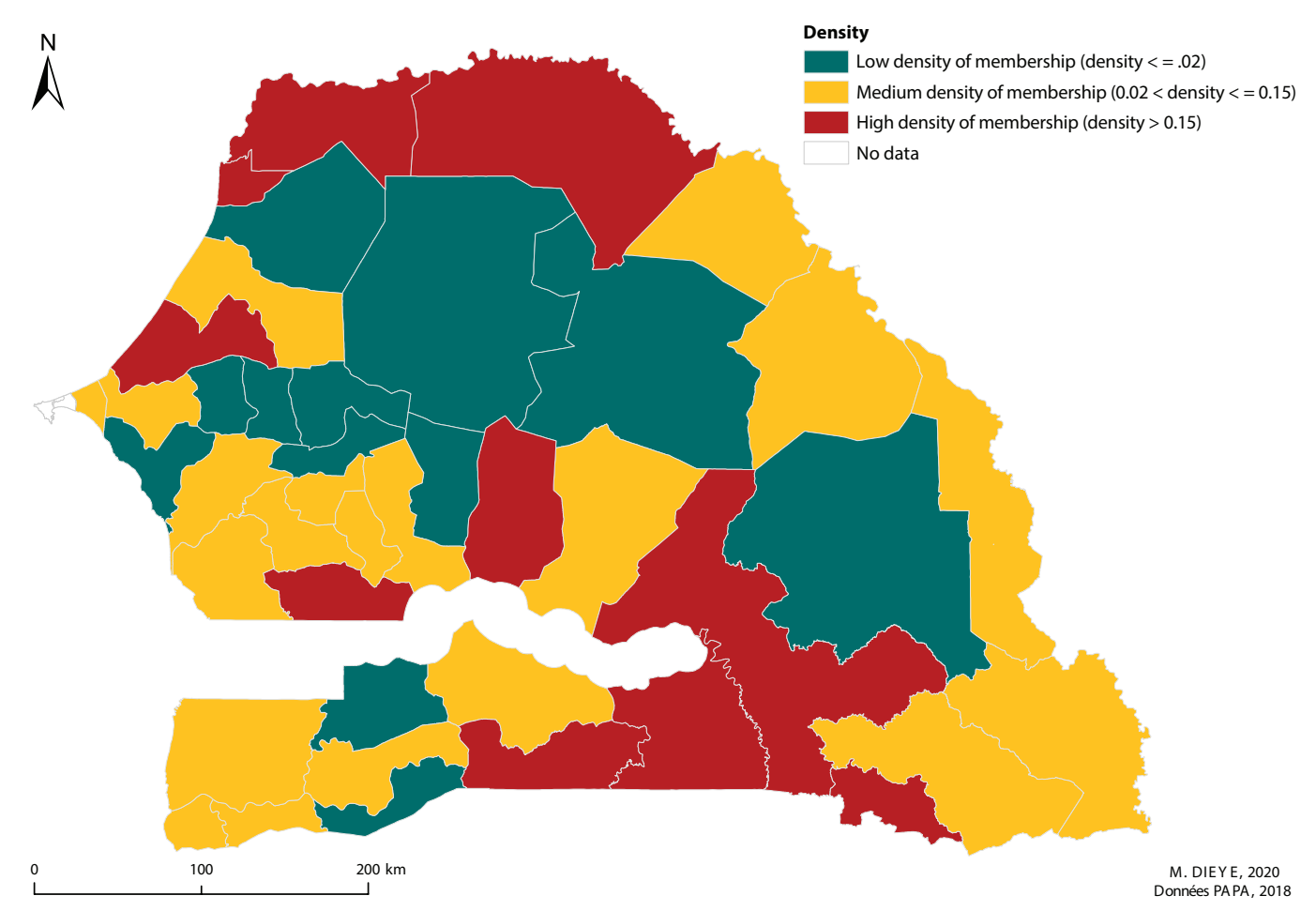

Source: Data from Projet d'Appui aux Politiques Agricoles survey, Senegal (2017).

\footnotetext{
2 In 2017, a total of 7,000 smallholders were surveyed in a nationally representative survey under PAPA. The survey included all rural departments of Senegal and covered dry cereal, rice, and horticulture producers.

3 This higher rate of membership is, of course, also a result of the sampling strategy that was followed for the horticulture and irrigated rice surveys.
}

divided by the total number of smallholders in a department. The density of membership in a producer organization is higher in (1) the Senegal River Valley in the departments of Dagana and Podor, in the Saint-Louis region; (2) part of the Niayes area in the coastal north, in the department of Tivaouane in the region of Thies; (3) the groundnut basin in the departments of Nioro du Rip in the region of Kaolack and Koungheul in Kaffrine; and (4) part of south and eastern Senegal in the departments of Kolda and Velingara, both in the region of Kolda, 


\section{FIGURE 8.2-PRODUCER ORGANIZATIONS IN SENEGAL}

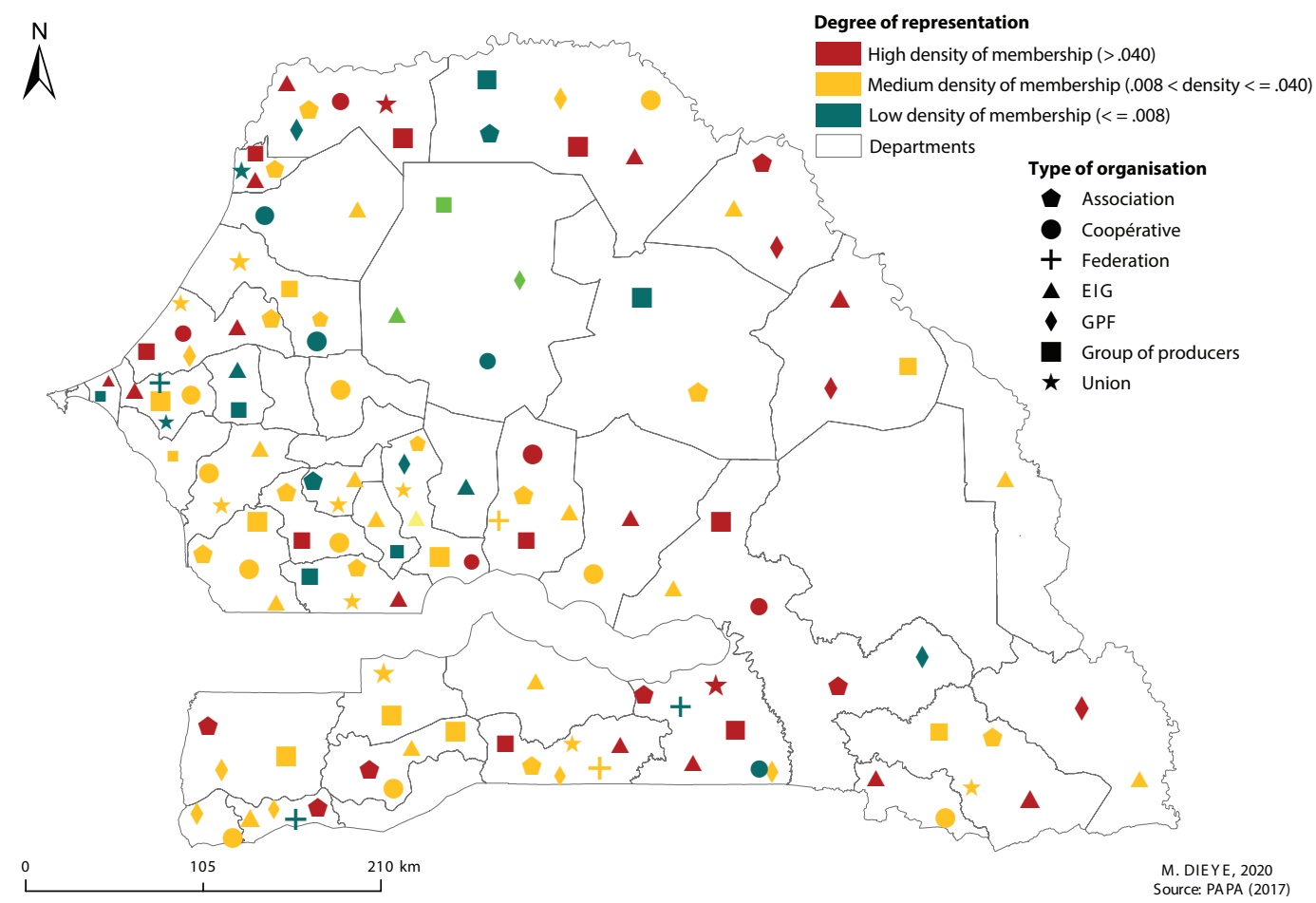

Source: Data from Projet d'Appui aux Politiques Agricoles survey, Senegal (2017).

Note: EIG = economic interest group; GPF = groupement de promotion feminine (women's advancement group). those engaged in irrigated production tend to have to organize to facilitate access to credit, inputs, and resources such as land and water (Fall 2015).

Figure 8.2 gives a spatial visualization of the institutional infrastructure across the country. In terms of heterogeneity and spatial representativeness of the different types of organizations across the country, we see that all types except federations are found throughout the country. Because federations are composed of lower-level organizations such as unions, which themselves are composed of village-level organizations, this is to be expected. It is also important to note that the density of organizations decreases from west to east. This is also to be expected because population density also decreases in the same manner.

Zooming in on the WUAs for which we have organizational-level data, a first thing to note is that although these associations operate in areas dominated by horticulture and most are involved in water management, their legal form tends to be an EIG or a women's advancement group (groupement de promotion feminine, or GPF). Average group size is about 100 members, and women tend to be overrepresented in most groups due to their being heavily involved in horticulture. We did not collect data on the timing of group establishment. A study of 50 horticulture organizations in Bakel mentions that these were largely established in the early 2000s and grew in membership at about 5 percent per year (Wouterse and Francesconi 2016). Table 8.1 shows that the WUAs in our sample offer a range of services and not all are involved in water

as well as Tambacounda region. These data are in line with the latest census of ANSD (2014), which showed these regions to be among the ones that have the highest rates of membership in producer organizations.

If we break down producer organizations by type, as in Figure 8.2, we see that membership in EIGs is most common, with around 9 percent of farms at the national level. As mentioned, EIGs are organizations with a more flexible legal status than that of cooperatives, in that they can be formed by at least two people in order to undertake a business activity, obtain credit, and the like. The rate of membership in EIGs is even higher for irrigated rice and horticulture producers, almost 23 and 17 percent, respectively. This is to be expected because management. It needs to be noted that most organizations offer more than one service.

\section{Empirical Strategy}

Technical efficiency can be defined as the ability of a decision-making unit (such as a farm) to produce maximum output given a set of inputs and technology. Production technology is commonly modeled by means of a production function. In microeconomic theory a production function is defined in terms of the maximum output that can be produced from a specified set of inputs, given 


\section{TABLE 8.1-ACTIVITIES OF ORGANIZATIONS}

Activity Share of organizations Managed collectively ( 1 = yes

Buying of inputs

0.83

0.84

Labor provision

Water management

Sales of outputs

Transport

Packaging

Storage

\begin{tabular}{|l|l|}
\hline 0.91 & 0.70 \\
\hline 0.67 & 0.74 \\
\hline 0.77 & 0.67 \\
\hline 0.51 & 0.66 \\
\hline 0.23 & 0.64 \\
\hline 0.17 & 0.60 \\
\hline
\end{tabular}

Source: Authors' computations based on data from Projet d'Appui aux Politiques Agricoles survey, Senegal (2017)

the existing technology available to the farms involved. The production frontier is a more general form of the production function and allows for the econometric exploration of the notion that, given the fixed local agroecological and economic conditions and the occurrence of random shocks that affect agricultural production, the investments, production decisions, and technological innovations a farmer makes may translate into higher or lower production and income. In such a context, inefficiency is defined as the loss incurred by operating away from the frontier, given the current prices and fixed factors faced by the smallholder (Aigner, Lovell, and Schmidt 1977).

When examining the impact of membership in producer organizations on the technical efficiency of smallholders using stochastic frontier analysis, we need to consider endogeneity due to self-selection into membership in a producer organization. Self-selection is likely to cause simultaneity bias if, for example, farming experience explains membership and also technical efficiency, or omitted variable bias, which occurs when an unobserved variable, such as ability, explains both membership and technical efficiency. We correct for both types of potential bias due to selectivity using PSM (see Ma, Abdulai, and Goetz 2018; Abate, Francesconi, and Getnet 2014; and Abdul-Rahaman and Abdulai 2018). In the PSM estimation framework, we use a binary choice model to generate a propensity score, corresponding to the probability of being a member of a farm organization, for each smallholder in our sample. Depending on the propensity scores, the PSM approach matches members of a producer organization and nonmembers who are similar in observed characteristics to address the potential selectivity bias resulting from observable factors. Tables with the results of the probit regression and descriptive statistics of observed characteristics are given in the appendix (Tables A8.1 and A8.2).

To analyze the relationship between the governance of producer organizations and their commercial performance for those who are involved in collective sales, we use both the quantity of produce commercialized collectively per member and the value of collectively commercialized produce as dependent variables (see also Bernard et al. 2014). Together, these data allow us to capture the notion that through bulking, producer organizations could gain bargaining power and negotiate higher prices for their members. To select our explanatory variables (summarized in Table A8.7), we base our work on Ostrom's (1990) design principles, discussed above. We use two indicators for boundaries, a variable for the number of activities that the group is engaged in and a variable for the number of activities that are managed collectively. To reflect conditions of usage and provision rules, we include a binary variable for the existence of a board and a variable that takes the value of 1 when decisions about management and organization are made by the general assembly. Monitoring is captured by a binary variable that takes the value of 1 if the organization has a system of accountability in place. The ability of the organization to enforce exclusion from services for noncontributors is captured by four binary variables that measure member obligations in terms of a membership fee, a regular contribution, attendance at meetings, and commitment to engagements. Conflict mediation is proxied by a binary variable that takes the value of 1 when a system of profit sharing is in place. Finally, to proxy the dedication of members to their enterprise and to each other, we include a binary variable that takes the value of 1 if the organization was established by members, and 0 otherwise.

\section{Estimation Results}

Results for our PSM — tables showing matching results, the covariate (im)balance of members and nonmembers, and the average treatment effect on the treated (ATT) (technical efficiency in this case) of membership using kernel and nearest neighbor matching-are given in the appendix in Tables A8.1 to A8.3. Figure 8.3 depicts a kernel density plot of technical efficiency estimates for members and nonmembers in the matched sample of smallholders. The figure shows that, correcting for selectivity, members of a producer organization are more technically 


\section{FIGURE 8.3-KERNEL DENSITY PLOT OF TECHNICAL EFFICIENCY OF PRODUCER ORGANIZATION MEMBERS AND NONMEMBERS (MATCHED SAMPLE)}

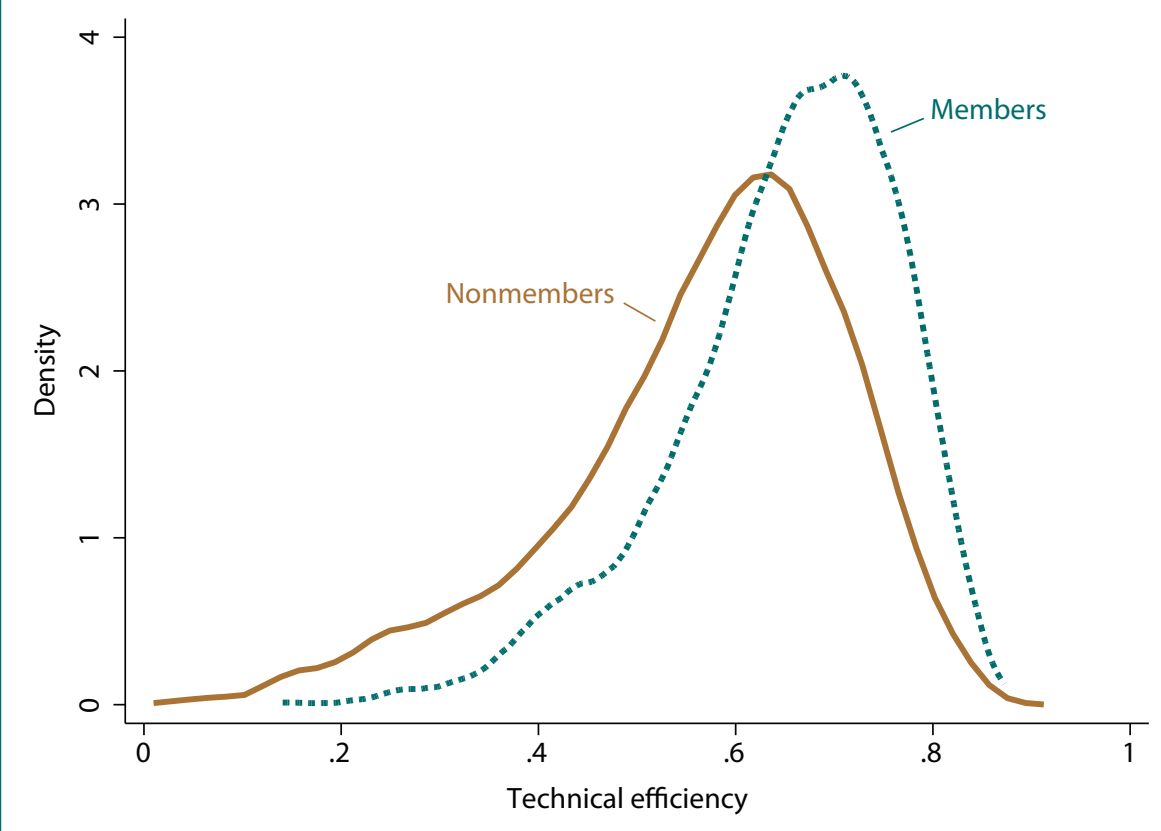

Source: Authors' computations based on data from Projet d'Appui aux Politiques Agricoles survey, Senegal (2017).

efficient, compared with nonmembers. A $t$-test confirms that this difference is significant. These results are in line with those of, for example, Abdul-Rahaman and Abdulai (2018) for rice farmers in Ghana, underlining that these organizations, by providing supply and marketing services, do address market failures.

Estimation results of the stochastic frontier and technical efficiency for the matched sample, given in Table A8.6 in the appendix, reveal that membership in a producer organization is indeed associated with lower inefficiency. Inefficiency is also explained by sex of the household head, with female heads being less efficient.

Table 8.2 shows results of the estimation of the relationship between governance of producer organizations and their commercial performance for those who are involved in collective sales.
TABLE 8.2-ORDINARY LEAST SQUARES REGRESSION

RESULTS OF COMMERCIAL PERFORMANCE

\begin{tabular}{|c|c|c|}
\hline Variable & $\begin{array}{l}\text { Produce sold } \\
\text { (kg/member) }\end{array}$ & $\begin{array}{l}\text { Value of produce } \\
\text { sold (FCFA/ } \\
\text { member) }\end{array}$ \\
\hline \multicolumn{3}{|l|}{ Governance } \\
\hline Established by members ( $1=$ yes) & $-40.30(23.26)^{\mathrm{a} *}$ & $-1.09(0.69)^{*}$ \\
\hline Existence of a board ( 1 = yes) & $33.85(20.22)^{*}$ & $1.42(0.58)^{* *}$ \\
\hline Decisions made by general assembly ( 1 = yes) & $39.71(21.45)^{*}$ & $1.37(0.75)^{*}$ \\
\hline Number of activities & $-10.63(6.89)$ & $-0.40(0.25)$ \\
\hline Number of collective activities & $9.61(5.89)^{*}$ & $0.42(0.18)^{* *}$ \\
\hline Membership fee (1 = yes) & $-24.68(17.92)$ & $-1.10(0.68)^{*}$ \\
\hline Regular contributions (1 = yes) & $-44.01(22.02)^{* *}$ & $-1.62(0.75)^{* *}$ \\
\hline Meeting attendance ( 1 = yes) & $10.58(27.53)$ & $1.27(0.80)^{*}$ \\
\hline Must honor commitments ( 1 = yes) & $0.71(28.73)$ & $-0.80(0.80)$ \\
\hline Profit sharing $(1=$ yes $)$ & $15.00(22.34)$ & $0.01(0.74)$ \\
\hline System of accountability ( 1 = yes) & $16.95(12.50)$ & $0.76(0.41)^{*}$ \\
\hline \multicolumn{3}{|l|}{ Controls } \\
\hline $\begin{array}{l}\text { Collective investment per member (in FCFA } \\
10,000 \text { s) }\end{array}$ & $-0.18(0.37)$ & $0.02(0.02)$ \\
\hline Land held by PO per member (ha) & $0.17(2.64)$ & $0.05(0.15)$ \\
\hline Collective output (kg) & $0.01(0.00)^{*}$ & $0.00(0.00)^{* *}$ \\
\hline Age of PO leader (years) & $1.15(0.73)$ & $-0.01(0.02)$ \\
\hline Sex of PO leader ( 1 = male) & $-97.35(30.08)^{* *}$ & $-1.79(1.07)^{*}$ \\
\hline Number of observations & 302 & 302 \\
\hline R-squared & 0.47 & 0.36 \\
\hline \multicolumn{3}{|c|}{$\begin{array}{l}\text { Source: Authors' computations based on data from Projet d'Appui aux Politiques Agricoles survey, Senegal } \\
\text { (2017). }\end{array}$} \\
\hline \multicolumn{3}{|c|}{$\begin{array}{l}\text { Note: a Robust standard errors in parentheses; ** denotes significance at the } 5 \text { percent level; }{ }^{*} \text { significance at } \\
10 \text { percent level. FCFA = Financial Community of Africa francs; } \mathrm{PO}=\text { producer organization. }\end{array}$} \\
\hline
\end{tabular}

Results in Table 8.2 show that the existence of a board is correlated with better commercial performance. In cooperatives, as in firms, the board's functions are to set strategic goals and develop an overarching vision for the organization. The finding here points to the role that leadership plays in the 
commercial performance of producer organizations, as also highlighted in empirical studies for Senegal by Bernard and colleagues (2014) and by Wouterse and Francesconi (2016). Establishment by members is associated with a smaller volume of collective sales and a lower value of sales. This could be because organizations established or supported by donors and governments usually benefit from more guidance and have access to new technologies including crop varieties and institutional arrangements with buyers. As a robustness check, we interact the level of collective investment with establishment by members, and find that the coefficient for being established by members is no longer significant; meanwhile, the negative, significant coefficient on the interaction term suggests that lower investment levels of organizations established by members explain their smaller volume of sales.

Management and organizational decisions made by the general assembly are associated with better performance. It is possible that decisions made at this level are more reflective of local conditions. Whereas the number of activities in which the organization is engaged has no bearing on performance, a greater number of activities that are managed collectively does. This could be because managing more activities collectively is associated with increased patronage. In terms of member obligations, results are rather mixed. Although financial obligations-membership fees and contributions-are associated with less collective commercialization, the requirement that members participate in meetings does correlate positively with the value of collective sales. Though these meetings are not social occasions, they do contribute to the connections between members and strengthen mutual concern, one of the cornerstones of sustainable collective action (Ben-Ner and Ellman 2013). The existence of a system of accountability is associated with a higher value of collective sales, though not with the volume of sales. It is also important to note that when an organization is headed by a female, this is associated with less produce sold collectively. A breakdown of the control variables by sex of the leader reveals that organizations headed by a woman hold less land, have a lower level of collective investment, and produce much less, compared with their counterparts headed by a male.

Although our results are correlations and should not be interpreted as suggestions of causal relations, it is evident that the design principles, as laid out by Ostrom (1990) and discussed above, and the governance of producer organizations relate to the commercial performance of such organizations in horticulture-producing areas of Senegal. Combining these results with the individual smallholder results suggests that there are two ways in which membership in producer organizations can improve smallholder productivity and income. First, members of producer organizations tend to be more technically efficient-that is, they are able to produce more output with a given level of inputs. Second, organizations that are carefully designed and governed to balance efficiency and equity objectives perform better economically. And precisely because these organizations are member owned, their performance translates directly into benefits for members.

\section{Conclusion and Policy Implications}

Senegal is a country with a vast wealth of rural institutions in thousands of villages as well as strong national-level organizations. Smallholder agriculture remains exposed to pervasive market failures that lead to missed opportunities and suboptimal economic behavior. These failures are often rooted in the importance of economies of scale in procuring inputs and marketing produce. Capitalizing on the existing institutional infrastructure that facilitates market exchange for smallholders is thus critically important, especially given that since 2012, Senegal has reprioritized its investments to catalyze an agriculturally led structural transformation. The country's development plan envisages agriculture as an engine of growth that will spur balanced economic and social development across multiple sectors.

A commonly held notion is that despite their long history and omnipresence, organizations of collective action in rural Senegal are relatively weak at delivering benefits to their members. It has been suggested that when design rules are not put in place, heterogeneity in member preferences threatens the viability of the cooperative organization because competing member-patron interests increase collective decision-making costs. If problems associated with collective action are not addressed, organizations can enter a state of dormancy, not engaging in commercial activities but instead solely serving as distributors of governmentsubsidized agricultural inputs. In addition, the performance of traditional producer organizations in Senegal is said to be hampered by the bureaucratic procedures and rules that characterize their governance structures. The EIGs and GPFs that were created in the late 1980s, following the onset of structural adjustment, have a more flexible legal status. When considering the role that producer organizations in rural Senegal can play in addressing market failures 
and enhancing smallholder production, it is thus important to take account of the various legal forms such organizations can take.

This paper has used data on almost 7,000 smallholders active in the cereal, rice, and horticulture value chains, along with organizational-level data for 395 WUAs in horticulture-producing areas of Senegal, to assess how producer organizations affect smallholder welfare. Correcting for selectivity by using PSM, we have shown that technical efficiency in agricultural production is significantly higher for those smallholders who are members of a producer organization. However, not all producer organizations are created equal, and design rules and governance are expected to affect the "robustness" of organizations and their ability to generate lasting benefits for their members. Using data for 395 WUAs-mainly EIGs and often made up solely of women - we show that these organizations are by no means dormant and are involved in several agriculturerelated activities. We have also empirically demonstrated, using regression analysis, that the design principles and the governance of these groups affect their commercial performance and thus the generation of benefits for their members.

In terms of policy implications, the role that producer organizations can play in the achievement of the country's economic and agricultural development is likely to be significant. Encouraging smallholders' membership in producer organizations is one policy measure that could contribute to the achievement of objectives such as intensification of family farming. Because design features and governance affect the level of benefits that these organizations can provide to their members in terms of collective commercialization, policies can also target the organizations themselves. There is a fine line, however, between interventions that could strengthen organizations and those that could be overly invasive. In general, producer organizations need to balance equity and efficiency objectives, and policymakers need to be sensitive to maintaining that balance. Finally, because female farmers appear significantly less efficient and female-headed producer organizations are less engaged in collective commercialization, policymakers would do well to adopt policies that are gender sensitive. 


\section{Appendix}

TABLE 8A.1-PROBIT REGRESSION FOR ORGANIZATIONAL MEMBERSHIP

\section{Variable \\ Membership}

Household size (number of members)

Schooling of highest educated adult

(years)

$0.03(0.00)^{* *}$

\begin{tabular}{l|l}
\hline Experience of head squared & $-0.00(0.00)^{* *}$
\end{tabular}

\begin{tabular}{l|l} 
Education of head (years) & $0.01(0.02)$
\end{tabular}

\begin{tabular}{l|l} 
Education of head squared & $-0.00(0.00)$
\end{tabular}

\begin{tabular}{l|l} 
Sex of household head $(1=$ female $)$ & $0.15(0.08)^{*}$
\end{tabular}

\begin{tabular}{l|l}
\hline Land holdings (ha) & $-0.02(0.00)^{* *}$
\end{tabular}

\begin{tabular}{l|l}
\hline Migrants in household (number) & $0.15(0.02)^{* *}$
\end{tabular}

\begin{tabular}{l|l} 
Nonfarm income (FCFA) & $0.00(0.01)$
\end{tabular}

\begin{tabular}{l|l}
\hline Number of observations & 6,458
\end{tabular}

\begin{tabular}{l|l} 
Pseudo R-squared & 0.06
\end{tabular}

Source: Authors' computations based on data from Projet d'Appu

aux Politiques Agricoles survey, Senegal (2017).

Note: Robust standard errors in parentheses; ** denotes

significance at the 5 percent level; ${ }^{*}$ significant at 10 percent.

FCFA = Financial Community of Africa francs.

\section{TABLE 8A.2-MEAN DIFFERENCE OF VARIABLES USED IN THE SELECTION EQUATION}

\section{\begin{tabular}{|l|l|l|l}
\hline Unmatched sample & Matched sample
\end{tabular}}

Nonmembers

Household size

Schooling of highest-educated adult

Experience of head

Education of head

Sex of head

Landholdings (ha)

Migrants in household (number)

Nonfarm income (FCFA)

Number of observations

Nonmembers Members

t-test

Nonmembers $\quad$ Members $t$-test

5,409

\begin{tabular}{l|l}
11.40 & -9.74 \\
7.59
\end{tabular}

11.33

7.33

\begin{tabular}{|c|c|}
\hline 11.27 & -0.23 \\
\hline 7.59 & 1.18 \\
\hline 45.14 & 0.31 \\
\hline 2.57 & 0.56 \\
\hline 0.95 & -0.05 \\
\hline 3.94 & 0.73 \\
\hline 0.57 & -0.32 \\
\hline 108,480 & 0.70 \\
\hline 1,083 & n.a. \\
\hline
\end{tabular}

Source: Authors' computations based on data from Projet d'Appui aux Politiques Agricoles survey, Senegal (2017)

Note: FCFA = Financial Community of Africa francs; n.a. = not applicable.

\section{TABLE 8A.3-AVERAGE TREATMENT EFFECTS}

\begin{tabular}{|l|c|c|c|c|c|c|c|}
\hline Technical efficiency & Sample & Member & Nonmember & Difference & S.E. & t-stat \\
\hline Kernel matching & Unmatched & 0.66 & 0.59 & 0.07 & 0.00 & 15.30 \\
\hline Nearest neighbor matching & ATT & 0.66 & 0.60 & 0.06 & 0.00 & 15.56 \\
\hline & ATT & 0.66 & 0.59 & 0.07 & 0.00 & 14.83 \\
\hline
\end{tabular}

Source: Authors' computations based on data from Projet d'Appui aux Politiques Agricoles survey, Senegal (2017).

Note: ATT = average treatment effect on those treated. 


\section{Appendix continued}

\section{TABLE 8A.4-ROBUSTNESS CHECK USING ROSENBAUM TEST}

\section{Rosenbaum bounds for delta ( $N=1,083$ matched pairs)}

\begin{tabular}{|c|c|c|c|c|c|c|}
\hline Gamma & $s i g+$ & $s i g-$ & $t$-hat + & $t$-hat- & $\mathrm{Cl}+$ & $\mathrm{Cl}$ - \\
\hline 1.0 & 0 & 0 & 0.073956 & 0.073956 & 0.067049 & 0.080766 \\
\hline 1.2 & 0 & 0 & 0.064763 & 0.082946 & 0.057424 & 0.089626 \\
\hline 1.4 & 0 & 0 & 0.056659 & 0.090316 & 0.049009 & 0.096820 \\
\hline 1.6 & 0 & 0 & 0.049439 & 0.096474 & 0.041538 & 0.102928 \\
\hline 1.8 & 0 & 0 & 0.042977 & 0.101740 & 0.034911 & 0.108160 \\
\hline 2.0 & $7.50 \mathrm{E}-15$ & 0 & 0.037199 & 0.106371 & 0.028866 & 0.112752 \\
\hline 2.2 & $3.10 \mathrm{E}-11$ & 0 & 0.031906 & 0.110448 & 0.023286 & 0.116905 \\
\hline 2.4 & $1.90 \mathrm{E}-08$ & 0 & 0.027039 & 0.114169 & 0.018133 & 0.120576 \\
\hline 2.6 & $2.60 \mathrm{E}-06$ & 0 & 0.022459 & 0.117484 & 0.013424 & 0.123879 \\
\hline 2.8 & 0.000114 & 0 & 0.018254 & 0.120505 & 0.009017 & 0.126872 \\
\hline 3.0 & 0.001971 & 0 & 0.014320 & 0.123233 & 0.004841 & 0.129604 \\
\hline 3.2 & 0.016421 & 0 & 0.010629 & 0.125768 & 0.000909 & 0.132118 \\
\hline 3.4 & 0.075974 & 0 & 0.007193 & 0.128093 & -0.002790 & 0.134465 \\
\hline 3.6 & 0.219854 & 0 & 0.003870 & 0.130228 & -0.006220 & 0.136687 \\
\hline 3.8 & 0.440789 & 0 & 0.000735 & 0.132220 & -0.009610 & 0.138748 \\
\hline 4.0 & 0.670987 & 0 & -0.002290 & 0.134111 & -0.012740 & 0.140728 \\
\hline
\end{tabular}

Source: Authors' computations based on data from Projet d'Appui aux Politiques Agricoles survey, Senegal
TABLE 8A.5-SUMMARY STATISTICS OF VARIABLES USED IN THE PRODUCTION FRONTIER AND TECHNICAL EFFICIENCY ESTIMATES

\begin{tabular}{|l|c|c|c|c|}
\hline Variable & Mean & Std. dev. & Min & Max \\
\hline Value of output (FCFA) & $1,189,091$ & $3,318,789$ & 0 & $112,000,000$ \\
\hline Land (ha) & 4.46 & 5.15 & 0.002 & 62 \\
\hline Household workers (number) & 3.09 & 2.27 & 1 & 22 \\
\hline Fertilizer (kg) & 657.18 & $2,987.26$ & 0 & 74,400 \\
\hline Cost of hired labor (FCFA) & 27,536 & 102,864 & 0 & $1,000,000$ \\
\hline Other costs (FCFA) & 21,806 & 156,745 & 0 & $10,100,000$ \\
\hline Value of equipment (FCFA) & 173,914 & 364,639 & 0 & $7,619,100$ \\
\hline Rice producer (1 = yes) & 0.10 & 0.31 & 0 & 1 \\
\hline Cereal producer (1 = yes) & 0.69 & 0.46 & 0 & 1 \\
\hline $\begin{array}{l}\text { 2016 rainfall deviation from 4-year } \\
\text { average (mm) }\end{array}$ & -27.99 & 73.44 & -296.80 & 188.08 \\
\hline Number of crops cultivated & 2.17 & 1.03 & 1 & 9 \\
\hline $\begin{array}{l}\text { Land rights through inheritance } \\
\text { (1 = yes) }\end{array}$ & 0.69 & 0.47 & 0 & 1 \\
\hline Number of observations & 6,513 & n.a. & n.a. & n.a. \\
\hline $\begin{array}{l}\text { Source: Authors' computations based on data from Projet d'Appui aux Politiques Agricoles survey, Senegal } \\
\text { (2017). } \\
\text { Note: FCFA = Financial Community of Africa francs; n.a. = not applicable. }\end{array}$ & & \\
\hline
\end{tabular}


TABLE 8A.6- ESTIMATION RESULTS OF PRODUCTION FRONTIER AND TECHNICAL EFFICIENCY FOR MATCHED SAMPLE

\begin{tabular}{|l|c|}
\hline Variable & $\begin{array}{c}\text { Value of output } \\
\text { (FCFA) }\end{array}$ \\
\hline Ln Land (ha) & $0.66(0.02)^{* *}$ \\
\hline Ln Household workers (number) & $0.10(0.02)^{* *}$ \\
\hline Ln Fertilizer (kg) & $0.11(0.01)^{* *}$ \\
\hline Ln Cost of hired labor (FCFA) & $0.02(0.00)^{* *}$ \\
\hline Ln Other costs (FCFA) & $0.02(0.00)^{* *}$ \\
\hline Ln Value of equipment (FCFA) & $0.03(0.02)$ \\
\hline Rice producer (1 = yes) & $1.63(0.07)^{* *}$ \\
\hline Cereal producer (1 =yes) & $0.42(0.06)^{* *}$ \\
\hline 2016 rainfall deviation from 4-year average (mm/100) & $-0.15(0.02)^{* *}$ \\
\hline Variable & $\begin{array}{c}\text { Technical } \\
\text { inefficiency }\end{array}$ \\
\hline Membership in a producer organization & $-0.59(0.12)^{* *}$ \\
\hline Household size & $-0.02(0.01)^{* *}$ \\
\hline Schooling of highest-educated adult & $-0.00(0.01)$ \\
\hline Experience of head & $0.01(0.00)^{* *}$ \\
\hline Education of head & $0.01(0.01)$ \\
\hline Sex of head & $-0.68(0.15)^{* *}$ \\
\hline Number of crops grown & $-0.02(0.04)$ \\
\hline Land rights through inheritance & $0.28(0.12)^{* *}$ \\
\hline $\begin{array}{l}\text { Source: Authors' computations based on data from Projet d'Appui aux Politiques } \\
\text { Agricoles survey, Senegal (2017). } \\
\text { Note: Robust standard errors in parentheses;** denotes significance at the } \\
5 \text { percent level; * significant at 10 percent. FCFA = Financial Community of Africa } \\
\text { francs. }\end{array}$ \\
\hline
\end{tabular}

TABLE 8A.7- SUMMARY STATISTICS OF VARIABLES USED TO EXPLAIN COMMERCIAL PERFORMANCE

\begin{tabular}{|l|c|c|c|c|}
\hline Variable & Mean & Std. dev. & Min & Max \\
\hline Produce sold (kg/member) & 124.64 & 439.94 & 0 & 6,000 \\
\hline Value of produce sold (FCFA/member) & 21,628 & 67,996 & 0 & 486,000 \\
\hline Established by members (1 =yes) & 0.58 & 0.49 & 0 & 1 \\
\hline Existence of a board (1 =yes) & 0.64 & 0.48 & 0 & 1 \\
\hline Decisions made by general assembly (1 = yes) & 0.38 & 0.49 & 0 & 1 \\
\hline Number of activities & 4.09 & 1.65 & 0 & 8 \\
\hline Number of collective activities & 3.02 & 2.10 & 0 & 7 \\
\hline Membership fee (1 = yes) & 0.63 & 0.48 & 0 & 1 \\
\hline Regular contributions (1 = yes) & 0.76 & 0.43 & 0 & 1 \\
\hline Meeting attendance (1 = yes) & 0.59 & 0.49 & 0 & 1 \\
\hline Must honor commitments (1 =yes) & 0.59 & 0.49 & 0 & 1 \\
\hline Profit sharing (1 = yes) & 0.35 & 0.48 & 0 & 1 \\
\hline System of accountability (1 = yes) & 0.61 & 0.49 & 0 & 1 \\
\hline Collective investment per member (FCFA/10,000) & 3.31 & 21.56 & 0 & 300 \\
\hline Land held by PO per member (ha) & 0.41 & 4.09 & 0 & 55.56 \\
\hline Collective output (kg) & 7,131 & 35,258 & 0 & 600,000 \\
\hline Age of PO head (years) & 50.18 & 10.49 & 23 & 80 \\
\hline Sex of PO head (1 = male) & 0.23 & 0.42 & 0 & 1 \\
\hline Number of observations & 395 & n.a. & n.a. & n.a. \\
\hline Source: Authors' computations based on data from Projet d'Appui aux Politiques Agricoles survey, Senegal (2017). & \\
\hline Note: FCFA = Financial Community of Africa francs; n.a. = not applicable; PO= producer organization. & & \\
\hline
\end{tabular}

